\title{
Pengaruh Gaya Kepemimpinan, Lingkungan Kerja dan Stres Kerja terhadap Kinerja Karyawan PT NT Cikarang
}

\author{
Sinta Sundari Heriyanti \\ Universitas Pelita Bangsa \\ $\underline{\text { Sinta_heriyanti@pelitabangsa.ac.id }}$
}

\section{Rahma Putri}

Universitas Pelita Bangsa

Rahma.puttri22@gmail.com

\begin{abstract}
This study aims to determine the effect of leadership style, work environment, and work stress on employee performance at PT. NT Indonesia. This type of research uses quantitative research. The sample in this study amounted to 74 respondents. Methods of data collection using a questionnaire. Data analysis using the SPSS program. The analysis used includes the analysis of the coefficient of determination, $F$ Test, and Multiple Linear Regression Test. The results showed that leadership style affected employee performance, work environment affected employee performance, job stress affected employee performance.
\end{abstract}

Keywords leadership style, work environment, work stress, employee performance.

\section{LATAR BELAKANG}

Dalam menghadapi beratnya tekanan persaingan seharusnya Indonesia telah berusaha meningkatkan kualitas sumber daya manusianya sejak tiga puluh atau dua puluh tahun yang lalu karena hanya sumber daya manusia yang handal yang dapat menjadi keunggulan kompetitif bagi negara berkembang seperti Indonesia untuk mendapatkan manfaat dari era globalisasi tersebut. Sumber daya manusia sebagai salah satu faktor internal yang memegang peranan penting berhasil tidaknya suatu organisasi dalam mencapai tujuan sehingga perlu diarahkan melalui manajemen sumber daya manusia yang efektif dan efisien. Cania (2014) menjelaskan bahwa sumber daya manusia diharapkan melalui ketrampilan, perilaku, dan sikap dapat mencapai kinerja yang dibutuhkan dalam organisasi. Namun apabila sebuah organisasi yang pencapaian kinerja pegawainya dihampir seluruh unit pelaksana menjadi belum maksimal. Sehingga penelitian ini dilakukan untuk mengetahui faktor yang mempengaruhi kinerja karyawan tersebut.

Salah satu hal yang dapat ditempuh perusahaan agar mampu bertahan dalam persaingan yang ketat yaitu dengan meningkatkan kinerja perusahaan dengan mempertahankan gaya kepemimpinan terhadap perusahaan. Karena kinerja suatu perusahaan merupakan modal, untuk mengerjakan produksi barang dan jasa pada perusahaan dan gaya kepemimpinan dari suatu perusahaan menjadi faktor pendorong dan pendukung dalam memimpin karyawan dalam 
meningkatkan kinerjanya. Segala usaha dilakukan untuk mencapai tujuan di antaranya dengan menggunakan sumber daya manusia yaitu tenaga kerja yang handal dan professional dan gaya kepemimpinan dari kinerja seorang pemimpin, dimana harus memiliki sifat yang ideal dan baik sehingga bisa meningkatkan kinerja karyawannya. Gaya kepemimpinan seorang dalam organisasi sangat penting dalam organisasi sangat penting dalam kemajuan sebuah perusahaan. Dari gaya kepemimpinan seorang baik dalam proses mengarahkan dan memberikan pengaruh terhadap karyawan atau bawahan penting agar tujuan perusahaan tercapai. Kata pimpin mengandung pengertian mengarahkan, membina atau mengatur, menuntun dan juga menunjukkan ataupun mempengaruhi. Secara teori perilaku karywan bergantung pada tipe kepemimpinan dan sulit untuk di identifikasi (Glynn \& DeJordy, 2010)

Gaya kepemimpinan dapat dijelaskan dalam skala mulai dari otokratis melalui demokrasi hingga partisipatif untuk menunjukan tingkat kewenangan dan keputusan yang membuat kekuatan pemimpin dan karyawan (Iqbal et al., 2015). Pemimpin mempunyai tanggung jawab baik secara fisik maupun spiritual terhadap keberhasilan aktivitas kerja dari yang dipimpin, sehingga menjadi pemimpin itu tidak mudah dan tidak setiap orang mempunyai kesamaan di dalam menjalankan ke-pemimpinannya. Untuk menunjukkan betapa pentingnya kepemimpinan dan betapa manusia membutuhkannya pemimpin yang baik ada pendapat yang keras yang mengatakan bahwa dunia atau umat manusia pada hakekatnya hanya ditentukan oleh beberapa orang saja, yakni yang berstatus sebagai pemimpin. Demikian juga dalam sebuah organisasi atau perusahaan. Pengarahan dari seorang pemimpin sangatlah penting terhadap usaha-usaha semua pekerja dalam mencapai tujuan-tujuan organisasi. Tanpa kepemimpinan atau bimbingan, hubungan antara tujuan perseorangan atau tujuan organisasi mungkin menjadi renggang. Oleh karena itu, kepemimpian sangat diperlukan bila suatu organisasi ingin sukses. Terlebih lagi pekerja-pekerja yang baik selalu ingin tahu bagaimana mereka dapat menyumbang dalam pencapaian tujuan organisasi, dan paling tidak, gairah pekerja memerlukan kepemimpinan sebagai dasar motivasi eksternal untuk menjaga tujuan-tujuan mereka tetap harmonis dengan tujuan organisasi, maka dari itu suatu organisasi akan berhasil atau bahkan gagal sebagian besar ditentukan oleh kepemimpinan tersebut. Disinilah diperlukan figur kepemiminan yang mampu berkomunikasi yang baik dan benar pada bawahannya, agar tujuan organisasi tetap terarah sesuai dengan perencanaan. Menurut Angayani (2016), kepemimpinan merupakan suatu kegiatan untuk dapat mempengaruhi perilaku orang lain, atau seni yang akan memengaruhi perilaku manusia baik perorangan maupun kelompok.

Kepemimpinan merupakan salah satu faktor yang sangat penting dalam suatu organisai karena berpengaruh akan keberhasilan ataupun kegagalan suatu organisai yang akan ditentukan oleh kepemimpinan tersebut. Adapun mengenai lingkungan kerja, seperti adanya pembagian mengenai tugas di lingkungan kerja tersebut tidak dapat dipisahkan satu sama lain. Antara keduanya harus saling seimbang, karena baik lingkungan kerja fisik maupun nonfisik samasama memengaruhi kinerja karyawan. Untuk menyeimbangkan keduanya diperlukan kesadaran pihak manajemen dari perusahaan tersebut. Oleh sebab itu, diperlukan lingkungan kerja yang kondusif untuk menunjang kinerja karyawan dalam melaksanakan pekerjaannya, agar hasil kerja yang diperoleh dapat tercapai secara optimal. 
Suatu kondisi lingkungan kerja dikatakan baik atau sesuai apabila manusia yang berada didalamnya dapat melaksanakan kegiatannya secara optimal, sehat, aman, dan nyaman. Kesesuaian lingkungan kerja dapat berdampak dalam waktu yang lama, demikian juga dengan lingkungan kerja yang buruk akan mengakibatkan sulitnya memperoleh sistem kerja yang efektif dan efisien. Dhermawan (2012) mengemukakan bahwa lingkungan kerja yang aman dan sehat terbukti berpengaruh terhadap produktivitas. Selain itu dikemukakan juga bahwa kondisi kerja yang menyenangkan dapat mencakup tempat kerja, dan fasilitas-fasilitas bantu yang mempercepat penyelesaian pekerjaa.

Penelitian yang dilakukan oleh Chao et al (2003), menjelaskan bahwa lingkungan yang tidak sehat dan nyaman akan menurukan tingkat produktivitas maupun moral pegawai sehingga akan memepengaruhi tujuan organisasi. Banyak perusahaan berkeyakinan bahwa lingkungan yang baik dan nyaman adalah faktor utama yang mempengaruhi hasil kinerja karyawan. Di sisi lain, agar roda perusahaan berjalan baik, adalah menjadi tugas manajemen supaya karyawan tidak mengalami stres kerja dan dapat memiliki semangat kerja dan moril yang tinggi serta ulet dalam bekerja. Untuk itu merupakan keharusan bagi perusahaan untuk mengenali faktor-faktor apa saja penyebab stres kerja agar membuat karyawan puas bekerja di perusahaan. Bila seorang karyawan mengalami stress kerja maka keadaan itu bisa mengakibatkan menurunnya prestasi kerja yang tentunya sangat merugikan diri karyawan dan perusahaan. Kebijakan organisasi termasuk kesempatan untuk berkembang, lingkungan kerja dan perilaku atasan. Berpengaruh besar terhadap stres atau tidaknya seorang karyawan. Walaupun stres pada umumnya dibahas dalam konteks negatif, stres juga mempunyai nilai positif.

Stres kerja dapat menjadi penyebab kinerja karyawan terganggu. Menurut Fajriansyah (2019) mengatakan bahwa terdapat hubungan langsung antara stress kerja prestasi kerja karyawan. Stres mempunyai potensi untuk mendorong atau mengganggu pelaksanaan kerja karyawan, tergantung dari seberapa besar tingkat stress. Hal ini sejalan dengan penelitian yang dilakukan oleh Wartono (2017) yang menjelaskan bahwa terdapat hubungan antara tingkat stress dengan kinerja yang di capai.

Stres merupakan suatu peluang bila stres itu menawarkan perolehan yang potensial adalah menjadi tugas manajemen agar karyawan mengelola stres kerja dan memiliki semangat kerja dan moril yang tinggi serta ulet dalam bekerja. Berdasarkan pengamatan sementara, fenomena gaya kepemimpinan yang terjadi pada PT. NT Indonesia adalah perilaku atau gaya memimpin seorang atasan dalam mengayomi atau memerintah kepada bawahannya, seringkali atasan memihak pada bawahan yang memiliki kedekatan pribadi terhadap atasan tersebut, keadaan ini menimbulkan keirian pada bawahan-bawahan lain, terutama pada yang merasa memiliki beban kerja yang lebih banyak ketimbang bawahan yang punya kedekatan khusus terhadap atasan. Sedangkan fenomena lingkungan kerja yang terjadi pada karyawan PT. NT Indonesia adalah lingkungan yang bekerja secara interpersonal. Disebut interpersonal karna keadaan lingkungan yang muncul adalah kendala antar karyawan dimana karyawan-karyawan tersebut membentuk kelompok-kelompok kecil sehingga menimbulkan persaingan antar kelompok. Hal ini dijelaskan oleh salah satu pimpinan PT. NT Indonesia, bahwa PT NT Indonesia karyawan melakukan persaingan secara tidak sehat sehingga menimbulkan kondisi 
lingkungan kerja menjadi kurang efektif, karena adanya persaingan antar kelompok, beban kerja yang tidak sesuai, atau dikatakan lingkungan kerja non fisik yang kurang baik, sedangkan fenomena stres kerja yang terjadi pada PT. NT Indonesia adalah adanya permasalahan dalam menentukan nilai capai target dalam menghasilkan barang produksi masih menggunakan perhitungan manual. Keadaan tersebut membuat karyawan menjadi stres fisik maupun non fisik.

\section{LANDASAN TEORI Kinerja Karyawan}

Kinerja berasal dari kata job performance atau actual performance yang berarti prestasi kerja atau prestasi sesungguhnya yang dicapai oleh seseorang. Pengertian kinerja adalah hasil kerja secara kualitas dan kuantitas yang dicapai oleh seorang pegawai dalam melaksanakan fungsinya sesuai dengan tanggung jawab yang diberikan kepadanya. Kinerja merupakan hasil atau keluaran dari suatu proses (Marsaoly \& Nurlaila, 2016). Kinerja merupakan perwujudan dari kemampuan dalam bentuk karya nyata. Menurut Sutedjo (2018), pengertian kinerja adalah hasil kerja secara kualitas dan kuantitas yang dicapai oleh seorang karyawan dalam melaksanakan tugasnya sesuai dengan tanggung jawab yang diberikan kepadanya. Menurut Suwatno (2011), kinerja merupakan tingkat keberhasilan pegawai dalam menyelesaikan pekerjaannya. Kinerja bukan merupakan karakteristik individu, seperti bakat, atau kemampuan, namun merupakan perwujudan dari bakat atau kemampuan itu sendiri. Kinerja merupakan gambaran mengenai tingkat pencapaian pelaksanaan suatu kegiatan kebijakan dalam mewujudkan sasaran, tujuan, misi dan visi organisasi yang tertuang dalam strategic planning suatu organisasi. Dapat disimpulkan dari beberapa pengertian diatas, bahwa Kinerja Karyawan adalah hasil kerja secara kualitas dan kuantitas yang dicapai oleh seorang karyawan dalam melaksanakan tugasnya sesuai dengan tanggung jawab yang diberikan kepadanya.

\section{Gaya Kepemimpinan}

Setiap pemimpin pada dasarnya memiliki perilaku yang berbeda-beda dalam memimpin bawahannya dan perilaku pemimpin tersebut disebut dengan gaya kepemimpinan. Dimana gaya kepemimpinan tersebut banyak mempengaruhi keberhasilan seorang pemimpin dalam mempengaruhi bawahannya. Gaya artinya sikap, Gerakan, tingkah laku, sikap elok gerak gerik yang bagus, kekuatan kesanggupan untuk beruat baik. Sednagkan gaya kepemimpinan adalah sekumpulan ciri yang digunakan pimpinan untuk mempengaruhi bawahan agar sasaran organisasi tercapai atau dapat pula dikatakan bahwa gaya kepemimpinan adalah pola perilaku dan strategi yang disukai dan sering diterapkan oleh seorang pemimpin (Rivai \& Sagala, 2009). Gaya kepemimpinan merupakan dasar dalam mengklasifikasikan tipe kepemimpinan. Gaya kepemimpinan adalah pola menyeluruh dari Tindakan seorang pemimpin, baik yang tampak maupun tidak tampak oleh bawahannya. Gaya kepemimpinan mengambarkan kombinasi yang konsisten dari falsafah, ketrampilan, sifat dan sikap yang mendasari perilaku seseorang.

\section{Lingkungan Kerja}

Lingkungan kerja merupakan bagian komponen yang sangat penting ketika karyawan melakukan aktivitas bekerja. Dengan memperhatikan lingkungan kerja yang baik atau menciptakan kondisi kerja yang mampu memberikan motivasi untuk bekerja, maka akan membawa pengaruh terhadap kegiatan kegairahan atau semangat karyawan dalam bekerja. Menurut Rivai (2009), lingkungan kerja merupakan elemen-elemen organisasi sebagai sistem 
sosial yang mempunyai pengaruh yang kuat di dalam pembentukan perliaku individu pada organisasi dan berpengaruh terhadap prestasi organisasi. Menurut Paramita (2013), lingkungan kerja terdiri dari lingkungan alam, lingkungan sosial, dan lingkungan budaya. Lingkungan alam merupakan lingkungan fisik yang belum atau tidak dipengaruhi budaya manusia, seperti cuaca, sinar matahari, dan sebagainya. Menurut Sedarmayati (2009) mendefinisikan bahwa lingkungan kerja maksudnya adalah keseluruhan alat perkakas dan bahan yang dihadapi, lingkungan sekitarnya di mana seseorang bekerja, metode kerjanya, serta pengaturan kerjanya baik sebagai perseorangan maupun sebagai kelompok. Menurut Rahmawanti (2014) mendefenisikan lingkungan kerja sebagai keseluruhan sarana prasarana kerja yang ada di sekitar pegawai yang sedang melaksanakan pekerjaan yang dapat mempengaruhi pekerjaan itu sendiri. Walaupun lingkungan kerja merupakan faktor penting serta dapat mempengaruhi kinerja pegawai, tetapi saat ini masih banyak perusahaan yang kurang memperhatikan kondisi lingkungan kerja perusahaannya. Suatu kondisi lingkungan kerja dapat dikatakan baik apabila lingkungan kerja tersebut sehat, nyaman, aman dan menyenangkan bagi pegawai dalam menyelesaikan pekerjaannya. Menurut Kristanti (2017) bahwa lingkungan kerja didesain sedemikian rupa agar dapat tercipta hubungan kerja yang mengikat pekerjaan dengan lingkungan. Lingkungan kerja yang menyenangkan dapat membuat para karyawan merasa betah dalam menyelesaikan pekerjaannya serta mampu mencapai suatu hasil yang optimal. Sebaliknya apabila kondisi lingkungan kerja tersebut tidak memadai akan menimbulkan dampak negatif dalam penurunan tingkat produktivitas kinerja karyawan.

\section{Stress Kerja}

Stres menunjukan adanya tekanan pada tubuh. Dalam psikologi, stress digunakan untuk menunjukan suatu tekanan atau tuntutan yang dialami individu atau organisme agar ia beradaptasi atau menyesuaikan diri. Gibson et al (2011), berpendapat bahwa Stress Kerja yaitu suatu tanggapan penyesuaian diperantarai oleh perbedaan-perbedaan individu dan atau proses psikologis yang merupakan suatu konsekuensi dan setiap tindakan dari luar (lingkungan), situasi, atau peristiwa yang menetapkan permintaan psikologis dan atau fisik berebihan kepada seseorang. Penelitian oleh Rivai (2009), berpendapat suatu kondisi ketegangan yang menciptakan adanya ketidak seimbangan fisik dan psikis, yang mempengaruhi emosi, pola berpikir, dan kondisi seorang karyawan. Dari beberapa definisi tersebut, dapat disimpulkan bahwa stres kerja adalah suatu kondisi dimana suatu karyawan mengalami suatu tekanan mental maupun fisik yang tidak dapat menyeimbangkan dengan tuntutan perusahaan.

\section{Pengembangan Hipotesis}

\section{Hubungan Gaya kepemimpinan dengan Kinerja Karyawan}

Gaya kepemimpinan memberikan pengaruh positif dan sifnifikan terhadap kinerja karyawan. Kualitas pemimpin tidak ditentukan oleh besar atau kecilnya hasil yang dicapainya, tetapi ditentukan oleh pola tingkah laku yang dirancang sedemikian rupa untuk mempengaruhi bawahannya agar dapat memaksimalkan kinerja yang dimiliki bawahannya sehingga kinerja organisasi atau tujuan perusahaan dapat dimaksimalkan. Pada penelitian Tampi (2014) menyatakan bahwa gaya kepemimpinan berpengaruh positif dan signifikan terhadap kinerja karyawan. Kepemimpinan memegang peranan penting karena pimpinan adalah seorang yang akan menggerakan dan mengarahkan organisasi dalam pencapaian tujuan dan seorang pemimpin perusahaan harus memiliki kemampuan mempengaruhi dan memberi motivasi pada 
karyawannya, yang berdampak pada peningkatan kinerja (Siagian \& Khair, 2018). Berdasarkan penjelasan tersebut dapat dirumuskan hipotesis:

H1: Gaya Kepemimpinan berpengaruh terhadap kinerja karyawan

\section{Hubungan Lingkungan Kerja dengan Kinerja Karyawan}

Pengaruh lingkungan kerja merupakan hal yang tidak boleh dikesampingkan oleh perusahaan karena akan berdampak pada kinerja karyawan yang berpengaruh terhadap perusahaan.Pengaruh lingkungan kerja adalah segala sesuatu hal atau unsur-unsur yang dapat mempengaruhi secara langsung maupun tidak langsung terhadap organisasi atau perusahaan yang akan memberikan dampak baik ataupun buruk terhadap kinerja karyawan. Putra (2013) menjelaskan bahwa lingkungan kerja berdampak besar dalam mempengaruhi kinerja karyawan. Perhatian terhadap lingkungan kerja bagi suatu perusahaan sangatlah penting karena berguna membantu kelancaran jalannya suatu perusahaan. Berdasarkan penjelasan tersebut dapat dirumuskan hipotesis:

H2: Lingkungan Kerja berpengaruh terhadap kinerja karyawan

\section{Hubungan Stress Kerja dengan kinerja karyawan}

Masalah stres kerja didalam organisasi menjadi gejala yang penting diamati sejak mulai timbulnya tuntutan untuk efisien didalam pekerjaan. Akibat adanya stres kerja tersebut yaitu orang menjadi nerveous, merasakan kecemasan yang kronis, peningkatan ketegangan emosi, proses berfikir dan kondisi fisik individu. Selain itu, sebagai hasil dari adanya stres kerja pekerja mengalami beberapa gejala stres yang dapat mengancam dan mengganggu kinerja mereka seperti mudah marah dan agresif, tidak dapat santai, emosi yang tidak stabil, sikap tidak mau bekerjasama, perasaan tidak mampu terlibat. Bagi seorang manajer (pemimpin) tekanantekanan yang diberikan kepada seseorang karyawan haruslah dikaitkan dengan apakah stres yang ditimbulkan oleh tekanan tersebut masih dalam keadaan wajar. Stres yang berlebihan akan menyebabkan seseorang frustasi dan dapat menurunkan kinerjanya, sebaiknya stres yang terlalu rendah menyebabkan karyawan tersebut baik bermotivasi untuk berkinerja baik. Menurut Aji (2017) karyawan memiliki kecenderungan stres yang tinggi tentang waktu, bekerja berjam-jam lebih lama lebih lama yang akan mengurangi dorongan karyawan untuk melakukan yang lebih baik, stres di lingkungan kerja mengurangi niat karyawan untuk melakukan lebih baik dalam meningkatkan pekerjaan. Jika stres meningkatkan kecenderungan karyawan untuk bekerja dengan baik menurun. Berdasarkan penjelasan tersebut dapat dirumuskan hipotesis:

H3: Stres Kerja berpengaruh terhadap kinerja karyawan

\section{METODE PENELITIAN}

Jenis penelitian ini adalah penelitian kuantitatif yang menguraikan suatu gejala atau fenomena yang mempengaruhinya disamping untuk mengetahui sebab dan akibat dari gejala tersebut melalui pembuktian. Selanjutnya, untuk mengetahui faktor-faktor apa saja yang mempengaruhi kinerja karyawan digunakan kuisioner sebagai instrumen penelitian dengan skala pengukuran menggunakan skala Likert melalui google form. Pengambilan sampel yaitu karyawan Dept. QA PT. NT Indonesia dengan jumlah 74 responden. Metode analisis data yang digunakan regresi linier berganda dengan bantuan Program SPSS. 


\section{HASIL DAN PEMBAHASAN \\ Koefisien Determinasi (R2)}

Analisis determinasi digunakan untuk mengetahui prosentase sumbangan pengaruh variabel independen secara bersama-sama terhadap variabel dependen. Pada intinya mengukur seberapa jauh kemampuan model dalam menerangkan variasi variabel dependen. Nilai koefisien determinasi (R2) dapat dilihat sebagai berikut ;

\section{Model Summary \\ Tabel 1. Hasil Koefisien Determinasi}

\begin{tabular}{lllll}
\hline Model & R & R Square & $\begin{array}{l}\text { Adjusted } \\
\text { Square }\end{array}$ & $\begin{array}{c}\text { R Std. Error of } \\
\text { the Estimate }\end{array}$ \\
\hline 1 &, $895^{\mathrm{a}}$ &, 754 &, 727 & 1,90669 \\
\hline
\end{tabular}

Sumber : Output Program SPSS , 2020

Berdasarkan output pada tabel 1 diperoleh angka Adjusted R Square sebesar 0,727 atau (72,7\%). Hal ini menunjukan bahwa presentase sumbangan pengaruh variabel independen sebesar 72,7\%. Maka, 72,7\% gaya kepemimpinan, stres kerja dan displin kerja berpengaruh terhadap kinerja karyawan sedangkan sisanya yaitu 27,3\% kinerja karyawan dipengaruhi oleh variabel-variabel lainnya yang tidak diteliti dalam penelitian ini.

\section{Uji F}

Uji F digunakan untuk menguji pengaruh variabel independen secara bersama-sama. uji $F$ pada dasarnya menunjukkan apakah semua variabel bebas yang dimasukkan dalam model mempunyai pengaruh secara bersama sama terhadap variabel terikat,dalam pengambilan keputusan apabila $\mathrm{F}$ hitung lebih besar dari $\mathrm{F}$ tabel dan signifikansi lebih besar dari 0,05 maka dapat dikatakan bahwa ketiga variabel bebas secara bersama-sama mempunyai pengaruh signifikan terhadap variabel terikat.

\section{Tabel 2. Hasil Uji F}

ANOVA ${ }^{\mathrm{a}}$

\begin{tabular}{|c|c|c|c|c|c|c|}
\hline Model & & $\begin{array}{l}\text { Sum } \\
\text { Squares }\end{array}$ & Df & Mean Square & $\mathrm{F}$ & Sig. \\
\hline \multirow[t]{3}{*}{1} & Regression & 187,083 & 3 & 62,361 & 12,807 &, $000^{b}$ \\
\hline & Residual & 340,863 & 70 & 4,869 & & \\
\hline & Total & 527,946 & 73 & & & \\
\hline
\end{tabular}

Sumber : Output Program SPSS , 2020

Berdasarkan tabel 2, diperoleh f hitung sebesar 62.361 sedangkan hasil f tabel sebesar 2,73. Maka fhitung > ftabel $(62.361>2,73)$ dan nilai sig sebesar 0,000 sig < 0,05 maka H0 ditolak dan Ha diterima. Artinya ada pengaruh secara bersama-sama (simultan) variabel gaya kepemimpinan, lingkungan kerja dan stres kerja terhadap variabel kinerja karyawan. Maka hipotesis penelitian yang menyatakan bahwa variabel bebas dan variabel terikat bersama-sama (simultan) dapat diterima. 


\section{Uji Analisis Regresi Berganda}

Analisis regresi berganda bertujuan untuk mengetahui pengaruh dua atau lebih variabel independent terhadap variabel dependent.Ringkasan hasil pengolahan data dengan menggunakan program SPSS tersebut adalah sebagai berikut :

Tabel 3.Hasil Uji Regresi Linear Berganda

\section{Coefficients ${ }^{\mathrm{a}}$}

\begin{tabular}{lllllll}
\hline & & \multicolumn{2}{l}{$\begin{array}{l}\text { Unstandardized } \\
\text { Coefficients }\end{array}$} & \multicolumn{2}{l}{$\begin{array}{l}\text { Standardized } \\
\text { Coefficients }\end{array}$} & \\
\cline { 2 - 4 } Model & $\mathrm{B}$ & Std. Error & Beta & T & Sig. \\
\hline 1 & $\begin{array}{l}\text { (Constant) } \\
\text { Gaya }\end{array}$ & 3,377 & 3,677 & &, 991 &, 359 \\
& $\begin{array}{l}\text { Kepemimpinan } \\
\text { Lingkungan }\end{array}$ &, 390 &, 0926 &, 691 & 6,330 &, 000 \\
&, 099 &, 815 &, 112 & 2,460 &, 003 \\
& $\begin{array}{l}\text { kerja } \\
\text { Stress Kerja }\end{array}$ &, 223 &, 099 &, 258 & 2,357 &, 030 \\
\hline
\end{tabular}

Sumber : Output Program SPSS , 2020

Berdasarkan output SPSS diatas, maka diperoleh persamaan regresi sebagai berikut :

$\mathrm{Y}=\mathrm{a}+\mathrm{b} 1 \mathrm{x} 1+\mathrm{b} 2 \times 2 \mathrm{Y}=3,377+0,390 \mathrm{X} 1+0,099 \mathrm{X} 2+0,223 \mathrm{X} 3$

Penjelasan persamaan tersebut adalah sebagai berikut : Konstan 3,377, Jika konstanta positif menunjukan pengaruh positif variabl independen (gaya kepemimpinan, lingkungan kerja dan stres kerja) bila variabel independen naik atau berpengaruh, maka variabel kinerja karyawan akan naik sebesar 3,377 atau terpenuhi. Koefisien variabel gaya kepemimpinan $=0,399$ Merupakan nilai koefisien regresi variabel gaya kepemimpinan terhadap variabel kinerja karyawan artinya jika gaya kepemimpinan mengalami kenaikan 0,399 atau 39,9 \% koefisien bernilai positif artinya antara gaya kepemimpinan dan kinerja karyawan hubungan positif. Kenaikan gaya kepemimpinan akan mengakibatkan kenaikan pada kinerja karyawan. Koefisien variabel lingkungan kerja sebesar 0,099, merupakan nilai koefisien regresi variabel lingkungan kerja terhadap variabel kinerja karyawan artinya jika lingkungan kerja mengalami penurunan, maka kinerja karyawan akan mengalami penurunan sebesar 0,099 \% atau 99\%. 4. Koefisien variabel stress kerja sebesar 0,223, merupakan nilai koefisien regresi variabel stres kerja terhadap variabel kinerja karyawan artinya jika stres kerja mengalami kenaikan 0,223 atau 22,3\% koefisien bernilai positif artinya antara stress kerja dan kinerja karyawan hubungan positif. Kenaikan stress kerja akan mengakibatkan kenaikan pada kinerja karyawan.

\section{Pembahasan}

\section{Pengaruh Gaya kepemimpinan terhadap kinerja karyawan}

Hipotesis pertama yang mempresentasikan pengaruh positif dan signifikan antara gaya kepemimpinan terhadap kinerja karyawan . Berdasarkan hasil uji parsial untuk variabel gaya kepemimpinan diperoleh thitung $=6,330$ dengan nilai signifikan 0,000 dengan probablitas signifikan jauh lebih kecil dari 0,05 dan nilai thitung lebih besar dari tabel $(6,330>1,994)$. Hal ini menunjukan bahwa $\mathrm{H} 0$ ditolak dan $\mathrm{H} 1$ diterima. Hasil penelitin ini menunjukan bahwa 
secara parsial variabel gaya kepemimpinan terdapat pengaruh variabel gaya kepemimpinan terhadap kinerja karyawan di PT. NT Indonesia. Semakin baik gaya kepemimpinan yang diberikan pemimpin kepada bawahan akan semakin tinggi pula kinerja karyawan. Maka dapat disimpulkan jika gaya kepemimpinan meningkat maka kinerja karyawan akan tinggi, sebaliknya jika gaya kepemimpinan melemah maka kinerja karyawan akan menurun atau rendah. Hasil ini di dukung dengan penelitian Ekhsan (2020), Martha et al (2020) yang menjelaskan bahwa adanya pengaruh gaya kepemimpinan terhadap kinerja karyawan. Gaya kepemimpinan berpengaruh terhadap kinerja karyawan.

\section{Pengaruh Lingkungan Kerja terhadap kinerja karyawan}

Hipotesis kedua yang mempresentasikan pengaruh positif lingkungan kerja kerja terhadap kinerja karyawan. Berdasarkan uji parsial untuk variabel lingkunga kerja kerja diperoleh thitung $=2,460$ dengan nilai signifikan 0,003 dengan probabilitas signifikan jauh lebih besar dari 0,05 dan nilai thitung lebih besar dari ttabel $(2,460>1,994)$. Hal ini menunjukan bahwa H0 ditolak dan $\mathrm{H} 2$ diterima hasil ini menunjukan bahwa secara parsial variabel lingkungan kerja kerja terdapat pengaruh variabel lingkungan kerja terhadap kinerja karyawan. Hasil ini di dukung oleh Wartono (2017) pengaruh lingkungan kerja terhadap kinerja karyawan. Lingkungan kerja berpengaruh positif terhadap kinerja karyawan.

\section{Pengaruh Stres Kerja terhadap kinerja karyawan}

Hipotesis ketiga yang mempresentasikan pengaruh positif stres kerja terhadap kinerja karyawan. Berdasarakan uji parsial untuk variabel stress kerja diperoleh thitung $=2,357$ dengan nilai signifikan 0,030 dengan probabilitas signifikan jauh lebih besar dari 0,05 dan nilai thitung lebih besar dari ttabel $(2,357>1,994)$. Hal ini menunjukan bahwa Ho di tolak dan $\mathrm{H} 3$ diterima hasil ini menunjukan bahwa secara parsial variabel displin kerja terdapat pengaruh displin kerja terhadap kinerja karyawan. Artinya semakin baik displin kerja karyawan maka akan semakin baik kinerja karyawan. Hasil ini didukung oleh Afifah (2020) pengaruh stres kerja terhadap kinerja karyawan. Stres kerja berpengaruh positif terhadap kinerja karyawan.

\section{KESIMPULAN}

Gaya kepemimpinan berpengaruh signifikan terhadap kinerja karyawan. Prioritas pimpinan dengan memberi kesempatan bawahan untuk aktif berpartisipasi dan melibatkan bawahan dalam pengambilan keputusan yang menjadi hak, tanggung jawab dan wewenang bawahannya. Lingkungan kerja berpengaruh signifikan terhadap kinerja karyawan. Lingkungan kerja yang baik mempunyai peran yang sangat besar dalam menunjang tercapainya tujuan perusahaan. Stres kerja berpengaruh signifikan terhadap kinerja karyawan. Stres kerja dapat menciptakan keunggulan kompetitif bagi perusahaan, tetapi apabila stress kerja yang dialami karyawan terlalu tinggi, maka kinerja karyawan akan terganggu.

\section{DAFTAR PUSTAKA}

Afifah, L. Z. (2020). pengaruh stres kerja, motivasi kerja dan keselamatan kerja terhadap kinerja karyawan dengan kepuasan kerja sebagai variabel mediasi (Studi Empiris Pada Perawat Rumah Sakit Rujukan COVID-19 Kota Magelang). Skripsi, Universitas Muhammadiyah Magelang. 
Aji, A. (2017). pengaruh motivasi kerja, stress kerja, dan keselamatan kerja terhadap kinerja karyawan pada pt. rosalia indah solo. Jurnal Ilmiah Universitas Muhammadiyah Surakarta. Manajemen. Surakarta.

Anggayani, N. L., Noak, P. A., \& Yudharta, I. P. D. (2016). Analisis Gaya Kepemimpinan Kepala Sekolah dalam Meningkatkan Kinerja Guru (Studi Kasus Sekolah Dasar Negeri 2 Pemecutan Kota Denpasar). Citizen Charter, 1(1), 165134.

Cania, L. (2014). The impact of strategic human resource management on organizational performance. Economia. Seria Management, 17(2), 373-383.

Chao, H. J., Schwartz, J., Milton, D. K., \& Burge, H. A. (2003). The work environment and workers' health in four large office buildings. Environmental Health Perspectives, 111(9), $1242-1248$.

Dhermawan, A. A. N. B., Sudibya, I. G. A., \& Utama, I. W. M. (2012). Pengaruh motivasi, lingkungan kerja, kompetensi, dan kompensasi terhadap kepuasan kerja dan kinerja pegawai di lingkungan kantor Dinas Pekerjaan Umum Provinsi Bali. Matrik: Jurnal Manajemen, Strategi Bisnis Dan Kewirausahaan.

Ekhsan, M., \& Nurlita, D. (2020). Pengaruh Gaya Kepemimpinan, Pelatihan dan Promosi Jabatan Terhadap Kinerja Karyawan. Jurnal Pengembangan Wiraswasta, 22(02), 113120.

Fajriansyah, m. i. (2019). hubungan antara stres kerja dan kepuasan kerja dengan kinerja karyawan pt. citra kerja terampil (ckt). universitas airlangga.

Gibson, J., Ivancevich, J., \& Konopaske, R. (2011). Organizations: Behavior, structure, processes. McGraw-Hill Higher Education.

Glynn, M. A., \& DeJordy, R. (2010). Leadership through an organization behavior lens. Handbook of Leadership Theory and Practice, 119-157.

Iqbal, N., Anwar, S., \& Haider, N. (2015). Effect of leadership style on employee performance. Arabian Journal of Business and Management Review, 5(5), 1-6.

Kristanti, E. (2017). Pengaruh Lingkungan Kerja Fisik dan Lingkungan Kerja Non Fisik terhadap Stres Kerja dan Dampaknya Terhadap Kinerja (Studi Pada Kantor Bersama Samsat Mojokerto Kota). Jurnal Ilmu Manajemen (JIM), 5(1).

Marsaoly, K. M. S., \& Nurlaila, N. (2016). Pengaruh Pengawasan Dan Disiplin Kerja Terhadap Kinerja Pegawai Pada Perwakilan Badan Kependudukan Dan Keluarga Berencana Nasional Provinsi Maluku Utara. Jurnal Manajemen Sinergi, 4(1).

Martha, A. R., Rahardjo, K., \& Prasetya, A. (2020). pengaruh gaya kepemimpinan transformasional terhadap kinerja karyawan dengan motivasi kerja sebagai variabel 
mediasi. profit: jurnal administrasi bisnis, 1-13.

Paramita, W., Prayuda, W. H., \& Handaru, A. W. (2013). Pengaruh lingkungan kerja dan budaya organisasi terhadap kepuasan kerja karyawan pada bank btn (persero) cabang Bekasi. JRMSI-Jurnal Riset Manajemen Sains Indonesia, 4(2), 257-275.

Putra, F. R. (2013). Pengaruh Lingkungan Kerja Terhadap Kinerja (Studi Pada Karyawan PT. Naraya Telematika Malang). Jurnal Administrasi Bisnis, 6(1).

Rahmawanti, N. P. (2014). Pengaruh lingkungan kerja terhadap kinerja karyawan (Studi pada karyawan kantor pelayanan pajak Pratama Malang Utara). Jurnal Administrasi Bisnis, $8(2)$.

Rivai, V., \& Sagala, E. J. (2009). Manajemen sumber Daya Manusia untuk Perusahaan, edisi kedua. Penerbit: Rajawali Pers, Jakarta.

Sedarmayanti, S. D. M., \& Kerja, P. (2009). Cetakan Ketiga, Bandung, CV. Mandar Maju.

Siagian, T. S., \& Khair, H. (2018). Pengaruh Gaya Kepemimpinan Dan Lingkungan Kerja Terhadap Kinerja Karyawan Dengan Kepuasan Kerja Sebagai Variabel Intervening. Maneggio: Jurnal Ilmiah Magister Manajemen, 1(1), 59-70.

Sutedjo, A. S., \& Mangkunegara, A. P. (2018). Pengaruh Kompetensi dan Motivasi Kerja terhadap Kinerja Karyawan di PT. Inti Kebun Sejahtera. BISMA (Bisnis Dan Manajemen), 5(2), 120-129.

Suwatno, H., \& Priansa, D. J. (2011). Manajemen SDM dalam organisasi Publik dan Bisnis. Bandung: Alfabeta.

Tampi, B. J. (2014). Pengaruh Gaya Kepemimpinan dan Motivasi terrhadap Kinerja karyawan pada PT. Bank Negara Indonesia, tbk (regional sales manado). Acta Diurna Komunikasi, $3(4)$.

Wartono, T. (2017). Pengaruh stres kerja terhadap kinerja karyawan (studi pada karyawan majalah Mother and Baby). KREATIF: Jurnal Ilmiah Prodi Manajemen Universitas Pamulang, 4(2). 